\title{
Front Matter: Volume 11523
}

, "Front Matter: Volume 11523," Proc. SPIE 11523, Optical Technology and Measurement for Industrial Applications 2020, 1152301 (15 June 2020); doi: $10.1117 / 12.2574753$

SPIE Event: SPIE Technologies and Applications of Structured Light, 2020, SPIE. Yokohama, Japan 


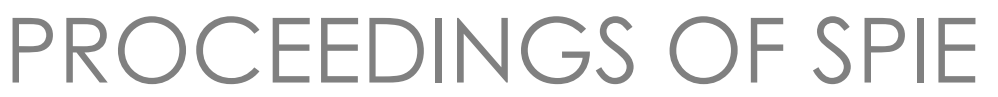

\section{Optical Technology and Measurement for Industrial Applications 2020}

Takeshi Hatsuzawa

Rainer Tutsch

Toru Yoshizawa

Editors

Yokohama, Japan

20-24 April 2020

Sponsored by

The Japan Society for Precision Engineering (JSPE)

SPIE

Published by

SPIE 
The papers in this volume were part of the technical conference cited on the cover and title page. Papers were selected and subject to review by the editors and conference program committee. Some conference presentations may not be available for publication. Additional papers and presentation recordings may be available online in the SPIE Digital Library at SPIEDigitalLibrary.org.

The papers reflect the work and thoughts of the authors and are published herein as submitted. The publisher is not responsible for the validity of the information or for any outcomes resulting from reliance thereon.

Please use the following format to cite material from these proceedings:

Author(s), "Title of Paper," in Optical Technology and Measurement for Industrial Applications 2020. edited by Takeshi Hatsuzawa, Rainer Tutsch, Toru Yoshizawa, Proceedings of SPIE Vol. 11523 (SPIE, Bellingham, WA, 2020) Seven-digit Article CID Number.

ISSN: 0277-786X

ISSN: 1996-756X (electronic)

ISBN: 9781510638532

ISBN: 9781510638549 (electronic)

Published by

SPIE

P.O. Box 10, Bellingham, Washington 98227-0010 USA

Telephone +1 3606763290 (Pacific Time) · Fax +1 3606471445

SPIE.org

Copyright (c) 2020, Society of Photo-Optical Instrumentation Engineers.

Copying of material in this book for internal or personal use, or for the internal or personal use of specific clients, beyond the fair use provisions granted by the U.S. Copyright Law is authorized by SPIE subject to payment of copying fees. The Transactional Reporting Service base fee for this volume is $\$ 21.00$ per article (or portion thereof), which should be paid directly to the Copyright Clearance Center (CCC), 222 Rosewood Drive, Danvers, MA 01923. Payment may also be made electronically through CCC Online at copyright.com. Other copying for republication, resale, advertising or promotion, or any form of systematic or multiple reproduction of any material in this book is prohibited except with permission in writing from the publisher. The CCC fee code is 0277$786 \mathrm{X} / 20 / \$ 21.00$.

Printed in the United States of America by Curran Associates, Inc., under license from SPIE.

Publication of record for individual papers is online in the SPIE Digital Library.

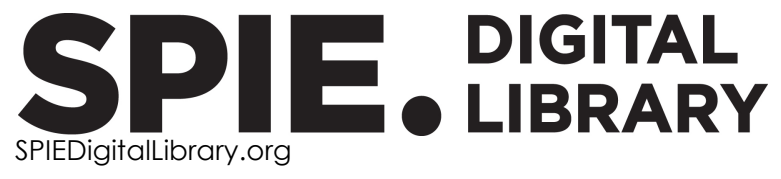

Paper Numbering: Proceedings of SPIE follow an e-First publication model. A unique citation identifier (CID) number is assigned to each article at the time of publication. Utilization of CIDs allows articles to be fully citable as soon as they are published online, and connects the same identifier to all online and print versions of the publication. SPIE uses a seven-digit CID article numbering system structured as follows:

- The first five digits correspond to the SPIE volume number.

- The last two digits indicate publication order within the volume using a Base 36 numbering system employing both numerals and letters. These two-number sets start with 00, 01, 02, 03, 04, $05,06,07,08,09,0 A, 0 B \ldots$ OZ, followed by 10-1Z, 20-2Z, etc. The CID Number appears on each page of the manuscript. 


\title{
Contents
}

\author{
$\checkmark \quad$ Authors \\ vii Conference Committee \\ ix Introduction
}

POLARIMETRY/ELLIPSOMETRY

1152302 Calibration methods for snapshot Mueller matrix spectropolarimetry [11523-10]

$1152303 \quad$ Fringe polarimetry enabled by the geometric phase: preliminary theory [11523-11]

NOVEL OPTICAL TESTING

$1152304 \quad$ Experimental investigation of multicore fiber Bragg grating's crosstalk for curvature sensing [1 1523-18]

SURFACE INSPECTION METHODS AND APPLICATIONS

$1152305 \quad$ Electromagnetic simulation model of microscopic scattering dark-field imaging for optical components surface defect detection [11523-6]

1152306 Simulation design of dark-field imaging scene for optical spherical surface imperfection based on raytracing [11523-8]

\section{APPLICATION OF INTERFEROMETRIC TECHNIQUES}

1152307 Optical and stress properties of flexible $\mathrm{Nb}_{2} \mathrm{O}_{5} / \mathrm{SiO}_{2}$ multi layer films deposited by $\mathrm{E}$-gun evaporation with ion-beam assisted deposition [1 1523-5]

1152308 Digital holographic microscope with a close set of two wavelengths [11523-14]

1152309 Acetylene photo-thermal spectroscopy using an optical heterodyne interferometer based on a double-pass acousto-optic frequency shifter [11523-15] 
UNIQUE OPTICAL SYSTEMS FOR INSPECTION AND MEASUREMENTS

$11523 \mathrm{OA}$ Investigation of retroreflector characteristics using computer-vision method [11523-16]

2D AND 3D MACHINE VISION METHODS AND APPLICATIONS

$11523 \mathrm{OB}$ The method of intelligent computer simulation of laser gyros behavior under vibrations to ensure their reliability and cost-effective development and production [11523-13]

STRUCTURED LIGHT METHODS, FRINGE PROJECTION MEASUREMENT AND APPLICATIONS

$115230 \mathrm{C}$ Fast 3D measurement system using generalized phase-shifting method for deformation measurement of human hand [11523-17]

SPHERICAL AND ASPHERICAL MEASUREMENTS

11523 OD Annular subaperture stitching interferometry with planar reference wavefront for measurement of spherical and aspherical surfaces [1 1523-1]

11523 OE Deep learning based method for phase analysis from a single closed fringe pattern [1 1523-12]

NOVEL INTERFEROMETRY

11523 OF Design of SiN waveguide reference wave source for point diffraction interferometer [11523-7]

INVITED SESSION

11523 OG Nano optical measurement for next-generation nano/micro manufacturing based on localized light energy control (Invited Paper) [11523-2]

$11523 \mathrm{OH} \quad$ Design of a spectroscopic imaging ellipsometer (Invited Paper) [11523-9]

iv 


\section{Authors}

Numbers in the index correspond to the last two digits of the seven-digit citation identifier (CID) article numbering system used in Proceedings of SPIE. The first five digits reflect the volume number. Base 36 numbering is employed for the last two digits and indicates the order of articles within the volume. Numbers start with 00, 01, 02, 03, 04, 05, 06, 07, 08, 09, OA, OB...0Z, followed by 10-1Z, 20-2Z, etc.

Abe, Tetsuya, 04

Bai, Jian, OF

Cao, Pin, 05

Chang, Chun-Hao, 07

Chen, Hsi-Chao, 07

Chen, Sheng-Bin, 07

Chen, Wei-Lin, 07

Chen, Yuankai, OF

Chou, Che-Chung, 09

Ehret, Gerd, OD

Futamura, Ikuo, 08

Garza-Soto, Luis, 03

Gelloz, Bernard, $\mathrm{OH}$

Golyaev, Yury, OB

Hagen, Nathan, 02

Han, Xiaokun, OA

Hayasaki, Yoshio, 08

He, Huayang, OA

$\mathrm{Hu}$, Haotian, 05

Huang, Pin-Wei, 09

lizuka, Yuki, $\mathrm{OH}$

Ishigaki, Hiroyuki, 08

Iwao, Takashi, $\mathrm{OH}$

$\mathrm{Ji}$, Chenchen, OE

Jin, Lianhua, $\mathrm{OH}$

Kobayashi, Shusuke, OC

Kofanov, Yury, OB

Kolbas, Yury, OB

Kondoh, Eiichi, $\mathrm{OH}$

Kurdybanskaia, Anastasiia, OB

Kuznetsov, Evgenii, OB

Kuznetsov, Nikita, OB

Li, Peihang, OE

$\mathrm{Li}$, Yao, OF

Liang, Zijian, OF

Lin, Tyson, 09

Liv, Shengan, OF

Lopez-Mago, Dorilian, 03

Lou, Weimin, 05

Lu, Ming-Feng, OE

Lu, Sheng-Hua, 09

LU, YU-RU, 07

Lu, Zichen, 05

Mamiya, Tkahiro, 08

Sanchez-Soria, Natalia, 03

Schake, Markus, OD

Soloveva, Tatiana, OB

Sonoda, Naohiro, 04

Su, Wenying, OA
Takahashi, Satoru, OG

Tanaka, Yosuke, 04

Tao, Ran, OE

Uehara, Makoto, $\mathrm{OH}$

Wang, Chen, OF

Wu, Jinmin, OE

$X$ Ue, Yingqi, $O A$

Yang, Yongying, 05, 06, OF

Yoshikawa, Nobukazu, OC

Yu, Gang, OE

Zhang, Danhui, 06

Zhang, Pengfei, 06

Zhao, Hongyang, OF 
Proc. of SPIE Vol. 11523 1152301-6

\section{Downloaded From: https://www.spiedigitallibrary.org/conference-proceedings-of-spie on 26 Apr 2023
Terms of Use: https://www.spiedigitallibrary.org/terms-of-use}




\title{
Conference Committee
}

\author{
Conference Chair
}

Takeshi Hatsuzawa, Tokyo Institute of Technology (Japan)

\section{Conference Co-Chairs}

Rainer Tutsch, Technische Universität Braunschweig (Germany) Toru Yoshizawa, Tokyo University of Agriculture and Technology (Japan)

\section{Conference Program Committee}

Masato Aketagawa, Nagaoka University of Technology (Japan)

Yasuhiko Arai, Kansai University (Japan)

Prathan Buranasiri, King Mongkut's Institute of Technology Ladkrabang (Thailand)

Jürgen W. Czarske, Technische Universität Dresden (Germany)

Motoharu Fujigaki, University of Fukui (Japan)

Amalia Martínez-García, Centro de Investigaciones en Óptica, A.C. (Mexico)

Satoshi Gonda, National Institute of Advanced Industrial Science and Technology (Japan)

Sen Han, University of Shanghai for Science and Technology (China)

Feng-Lei Hong, Yokohama National University (Japan)

Nathan Hagen, Utsunomiya University (Japan)

Hideki Ina, Canon Inc. (Japan)

Ichiro Ishimaru, Kagawa University (Japan)

Lianhua Jin, University of Yamanashi (Japan)

Daesuk Kim, Chonbuk National University (Korea, Republic of)

Jonathan D. Kofman, University of Waterloo (Canada)

Kazuhide Kamiya, Toyama Prefectural University (Japan)

Qian Kemao, Nanyang Technological University (Singapore)

Fumio Koyama, Tokyo Institute of Technology (Japan)

Ryoichi Kuwano, Hiroshima Institute of Technology (Japan)

Yu-Lung Lo, National Cheng Kung University (Taiwan)

Yasuhiro Mizutani, Osaka University (Japan)

Christian Rembe, Technische Universität Clausthal (Germany)

Yukitoshi Otani, Utsunomiya University (Japan)

Pavel Pavlicek, Palacký University Olomouc (Czech Republic)

Takamasa Suzuki, Niigata University (Japan)

Satoru Takahashi, The University of Tokyo (Japan)

Toshiyuki Takatsuji, National Institute of Advanced Industrial Science and Technology (Japan) 
Toshitaka Wakayama, Saitama Medical University (Japan)

Wei-Chung Wang, National Tsing Hua University (Taiwan)

Gao Wei, Tohoku University (Japan)

Jiangtao Xi, University of Wollongong (Australia)

Hayato Yoshioka, Tokyo Institute of Technology (Japan)

Song Zhang, Purdue University (United States) 


\section{Introduction}

The first Optical Technology and Measurement for Industrial Applications Conference (OPTM) was held in Minatomirai, Yokohama JAPAN from 23 to 25 April 2019, as a part of the Optics and Photonics International Congress 2019, sponsored by the SPIE and Mechano-optics technical committee in the Japan Society of Precision Engineering. In the conference, 35 oral presentations and 15 posters were presented, which quite a lot for a first time. The topics are full of variety ranging from profilometry, data acquisition, metrology, inspection etc., showing deep interests in this technical field.

The aim of the OPTM 2020 is to provide an international opportunity for introducing up-to-date technology in the field of optical measurement and their applications for industries while at the same time, providing a networking opportunity for young researchers and students; which is another important role of the conference. Also in the venue, other optics related exhibitions and conferences will be held which is a good chance to foster interest in different technical fields. We hope your visit to the port of Yokohama will represent a new step in your technical and research career.

\section{Takeshi Hatsuzawa Rainer Tutsch Toru Yoshizawa}


Proc. of SPIE Vol. 11523 1152301-10

Downloaded From: https://www.spiedigitallibrary.org/conference-proceedings-of-spie on 26 Apr 2023 Terms of Use: https://www.spiedigitallibrary.org/terms-of-use 